Abant Tıp Dergisi

Olgu Sunumu / Cilt 10 Sayı 1 YII 2021
Abant Medical Journal

Case Report / Volume 10 Issue 1 Year 2021

\title{
Her Gerçek Umbilikal Kord Düğümlenmesi Acil Doğum Gerektirmez
}

Every True Umbilical Cord Knot May Not Require Emergency Delivery

Banuhan ŞAHIN

Amasya University Sabuncuoglu Serefeddin Training and Research Hospital, Department of Gynecology and Obstetrics, Amasya, Türkiye

\section{Öz}

Göbek kordonunun gerçek düğümü, perinatal yönetimde nadir görülen bir anormalliktir ve obstetrisyenler için çoğunlukla korkulan bir durumdur. Göbek kordonunun gerçek düğümü sıkılaştığında, gebelik haftasından bağımsız olarak fetal dolaşımın engellenmesine, gelişme geriliğine ve hatta intrauterin ölüme dahi yol açabilmektedir. Buna karşılık, göbek kordonunun gerçek düğümü antenatal dönemde herhangi bir belirti vermeyebilir ve bebekler sağlıklı doğabilmektedir. Burada, elektif sezaryen sırasında rastlantısal olarak karşılaşılan göbek kordonunun gerçek düğümü olgusunu literatür ışığında sunmayı amaçladık.

Anahtar Kelimeler: acil, doğum, elektif sezaryen, göbek kordonunun gerçek düğümü.

\begin{abstract}
A true knot of the umbilical cord is a rare abnormality and most feared condition in perinatal management for obstetricians. When the true knot of the umbilical cord becomes tight, it can lead to the obstruction of the fetal circulation, development retardation, and even intrauterine death regardless of gestational week. In contrast, the true knot of the umbilical cord may not show any symptoms in the antenatal period and babies can be born in good health. Herein, we aimed to present a case of a true knot of the umbilical cord that was coincidentally encountered during elective cesarean section in the light of the literature.
\end{abstract}

Keywords: delivery, emergency, elective cesarean section, true knot of umbilical cord.

\section{INTRODUCTION}

The incidence of true knot of umbilical cord is around $1-2 \%$ of all deliveries (1). Predisposing factors include advanced maternal age, long cord, poly-hydramnios, intrauterine growth restriction, mono-amniotic twins, male fetuses, gestational diabetes mellitus, and multiparity. It is a difficult situation to diagnose antenatally, even with the help of the ultrasound. Most knots are loose with no clinical significance, though there exists an association between cord knots and intrauterine death (2).

Acute umbilical disorders (by compression, knot, or prolapse) are relatively rare obstetric events that could significantly affect perinatal morbidity, in this case report we present a case of a multigravida who delivered a healthy baby with a true knot of umbilical cord.

Case: A 43 years old, G2P1 woman was admitted at 39th week of her pregnancy for elective cesarean section. Her last baby was delivered by cesarean section 2 years earlier. She had regular antenatal checkups and the antenatal period was uneventful except her serum glucose levels because of uncontrolled gestational diabetes. Her antenatal ultrasound examinations were within normal limits. She delivered an alive and healthy male baby of 3815 grams with an APGAR score of 9 and 10 in one and five minutes. There was no abnormal amniotic fluid or meconium staining. The placenta was in normal appearance and easily removed. The cord measured $70 \mathrm{~cm}$, had one true knot in $20 \mathrm{~cm}$ of beginning (Image). One month after delivery the baby was still found in good health.

Although the onset of the knot was not determined, the maximum longitudinal development of the umbilical cord, combined with the large quantity of amniotic fluid and fetal 
movements, occurs before the end of the second trimester. Moreover, the umbilical blood flow increases over the course of the pregnancy. In this case, the true umbilical cord knot remained hidden prenatally due to lack of a characteristic ultrasound appearance.

\section{CASE REPORT}

The umbilical cord is called the fetal life line. Various abnormalities are observed in the morphology and pathology of the umbilical cord. A true knot of umbilical cord may cause fetal hypoxia or even intrauterine death (3). Umbilical cord true knots during the second trimester are rare causes of abortions though it is said that its presence during the third trimester and labor is not associated with increased perinatal morbidity and mortality (4). Wharton's jelly protects and isolates the umbilical blood vessels, preventing the early collapse of structures within an umbilical cord knot. Thus, the fetal risk is greater when the cord's diameter is smaller, as in the case of an old knot containing and obstructive cord lesions have been linked to fetal thrombotic vasculopathy and long-term neurological damage (5). The ultrasonographical appearance has been described as similar to a four-leaf clover, but this pattern is nonspecific and can be seen with false knots or closely apposed loops of umbilical cord. Use of color Doppler ultrasound, particularly threedimensional power Doppler Imaging, may support the suspected diagnosis especially in the 3rd trimester (6). (Figure 1).

True knots are generally single and loose. However, tight or multiple true knots and knots associated with coiling or twisting of the cord, increase the risk of intrauterine demise. The medical record should document the presence of a true knot, which is hard to discover prenatally, the tightness or laxity of the knot, the presence of unilateral edema of the cord relative to the knot, and whether there are thrombi in the vessels (7).
In the majority of cases, true knots of the umbilical cord occur without any clinical significance. A 4-fold increase in fetal loss have been reported to result from true knot, seemingly because the umbilical cord vessels can be compressed when the knot tightens (8). The majority of knots seem to be protected against occlusion by the greater thickness of Wharton's jelly and the large cord radius at the gestational age near term. If loose, a true knot will not lead to fetal compromise since fetal circulation is maintained.

\section{DISCUSSION}

The prenatal observation of knots of the umbilical cord creates an ethical dilemma for obstetricians whether to inform the mother of the finding and the risks related to this condition, as well as the potential medical-legal implications. Even so, should not be afraid of every true knot of umbilical cord and should reduce induced labor and emergency cesarean rates due to anxiety.

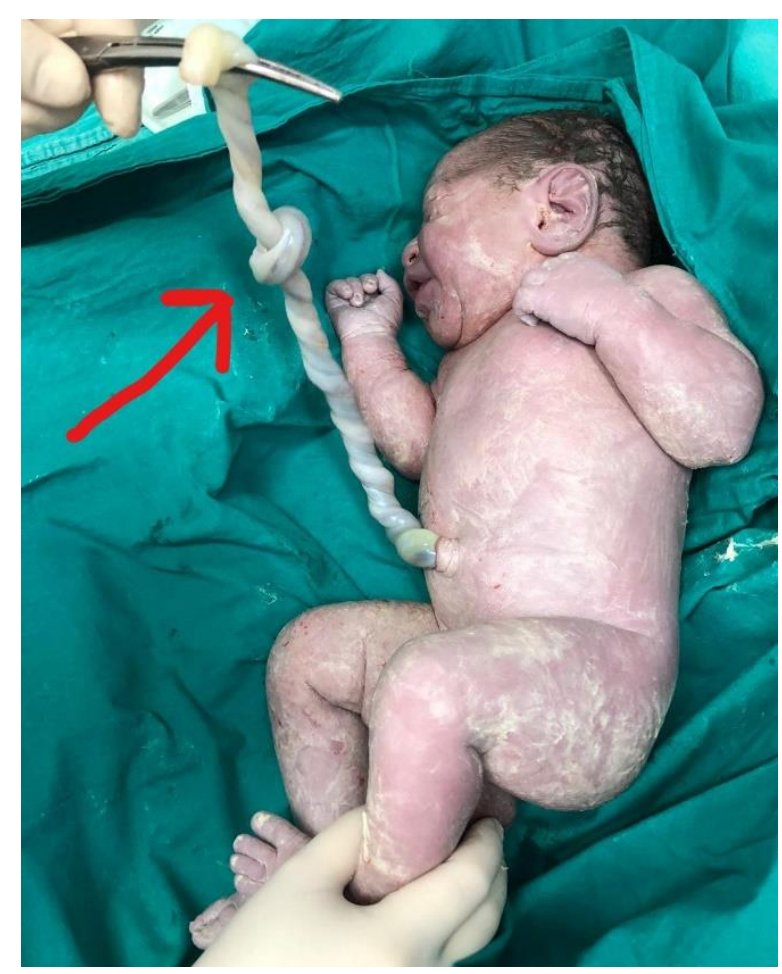

Figure 1. True umblical cord knot

Informed Consent: Written consent was obtained from the participants. 
Conflict of Interest: Authors declared no conflict of interest.

Financial Disclosure: Authors declared no financial support.

\section{REFERENCES}

1. Räisänen S, Georgiadis L, Harju M, Keski-Nisula L, Heinonen S. True umbilical cord knot and obstetric outcome. Int J Gynaecol Obstet 2013; 122(1): 18-21.

2. Chan JSY, Baergen RN. Gross umbilical cord complications are associated with placental lesions of circulatory stasis and fetal hypoxia. Pediatr Dev Pathol 2012; 15: 487-94.

3. Sel G. True Knot of the Umbilical Cord Leading to Third Trimester Fetal Demise. Archive of Medical Investigations 2017; 2: 17-8.

4. Bakas P, Papadakis E, Hassiakos D, Liapis A. Secondtrimester miscarriage and umbilical cord knot. Case report and review of the literature. Clin Exp Obstet Gynecol 2013; 40: 448-51.

5. Stanek J. Association of coexisting morphological umbilical cord abnormality and clinical cord compromise with hypoxic and thrombotic placental histology. Virchows Arch 2016; 468(6): 723-32.

6. Scioscia $M$, Fornalè $M$, Bruni $F$, Peretti $D$, Trivella $G$. Four dimensional and Doppler sonography in the diagnosis and surveillance of a true cord knot. J Clin Ultrasound 2011; 39: 157-9.

7. Hasbun J, Alcalde JL, Sepulveda W. Three-dimensional power Doppler sonography in the prenatal diagnosis of a true knot of the umbilical cord: value and limitations. J Ultrasound Med 2007; 26: 1215.

8. Hershkovitz R, Silberstein T, Sheiner E, Shoham-Vardi I, Holcberg G, Katz M, et al. Risk factors associated with true knots of the umbilical cord. Eur J Obstet Gynecol Reprod Biol 2001; 98: 36-9. 